\title{
Die ontwerp van 'n Afrikaanse taakgebaseerde rekenaaronderrig- program vir internasionale studente aan die Universiteit Stellenbosch
}

\author{
Vernita Beukes \\ Taalsentrum, Universiteit Stellenbosch, Suid-Afrika \\ E-pos: vernita@sun.ac.za \\ Elbie Adendorff \\ Departement Afrikaans en Nederlands, Universiteit Stellenbosch, Suid-Afrika \\ E-pos: elbie@sun.ac.za
}

\section{Opsomming}

Die navorsing waaroor in hierdie artikel verslag gelewer word, is spesifiek gerig op nieAfrikaanssprekende internasionale studente aan die Universiteit Stellenbosch (US). Die doel van die breë navorsing wat onderneem word en waarvan in dié artikel slegs gedeeltelik verslag gelewer word, is om die moontlike ontwerp van 'n taakgebaseerde rekenaarprogram vir die kursus Beginner Afrikaans Vlak 1 te illustreer. Die navorsing val binne twee breë vakgebiede, waarvan die eerste een die takkgebaseerde benadering tot leer en onderrig is en die tweede een rekenaargesteunde taalonderrig (RGTO). Taakgebaseerde leer en onderrig is 'n onderrigbenadering waar die fokus van die studente op die bereiking van 'n doelwit geplaas word. Volgens Duran en Ramaut (2006) en Van Avermaet en Gysen (2006) is die vertrekpunt van enige taakgebaseerde benadering 'n behoefte-analise. Vir hierdie studie het die studente 'n vraelys voltooi. As deel van die behoefte-analise gebruik die studente, saam met die vraelys, die Europese Referensiekader (ERK) (2001) om hulle taalvaardighede te assesseer. Die studente verskaf ook inligting oor onderwerpe wat hulle graag in die klas behandel wil hê. Nadat die taakgebaseerde benadering bespreek is, word daar op Mayer $(2009,2011)$ se kognitiewe teorie van multimedialeer gefokus. Dit dien as vertrekpunt vir die tweede vakgebied, naamlik rekenaargesteunde taalonderrig (RGTO) wat verder in hierdie artikel bespreek word. Hierdie teorie verskaf die agtergrond vir enige aktiwiteit wat op die rekenaar ontwerp word. Nadat die kognitiewe teorie van multimedia-leer bespreek is, word daar op vier multimedia-instruksiebeginsels, deur Mayer (2009, 2011) ontwikkel, gefokus, naamlik die oortolligheidseffek, die samehangeffek, die ruimtelike-aangrensingseffek en die verpersoonlikingseffek. Hierdie beginsels word kortliks bespreek, voordat ' $n$ verbinding tussen die twee vakgebiede gemaak word deur die bevindinge wat sover van studente verkry is, te gebruik en dan prakties te toon hoe een van die instruksiebeginsels moontlik aan die studente voorgestel kan word in die rekenaarprogam.

Sleutelwoorde: taakgebaseerde benadering, behoefte-analise, rekenaargesteunde taalonderrig (RGTO), kognitiewe teorie van multimedia-leer 


\section{The design of an Afrikaans task-based computer program for international students at Stellenbosch University}

\section{Extended abstract}

The focus of the research discussed in this article is on non-Afrikaans-speaking international students who are served by the Language Centre at Stellenbosch University. The aim of the broad research of which only a part is reported on in this article, is to describe the steps taken in the design of a task-based computer program for the course Beginner Afrikaans Level 1.

The Postgraduate and International Office (PGIO) at Stellenbosch University offers several courses for international students. Students have to choose a minimum of five courses in order to transfer the required amount of credits back to their home universities. The Language Centre has close ties with the Postgraduate and International Office because of the language acquisition courses which they present to international students.

Foreign students who wish to become proficient in Afrikaans during their stay in South Africa choose to enrol for Beginner Afrikaans Level 1. One of the objectives of this course is that students acquire the Afrikaans being used in social contexts on and around campus. The course focuses primarily on communicative and discourse competencies. Students follow the course for one semester and have class for four hours per week for fourteen weeks. Being a creditbearing course, students obtain twelve South African university credits for it.

The students who follow this course are mainly from America and Europe and more detail on their backgrounds is given in the article. These students mentioned in formal feedback sessions that they would like to have a computer component as part of the course and this request forms the basis for the study.

The research bridges two broad disciplines: the task-based approach to teaching and learning (TBTL) and computer assisted language learning (CALL).

Task-based teaching and learning is an educational approach where the focus is on achieving a goal; where language becomes the tool and using the language a necessity. According to Duran and Ramaut (2006) and Van Avermaet and Gysen (2006) the starting point of any task-based approach is a needs analysis in order to identify student needs. In this study a needs analysis was conducted specifically to determine why students enrol for this course. In addition the students provided information on topics they would like to cover in class and completed a questionnaire.

Besides the completion of a needs analysis and questionnaire, the students used the Common European Framework of Reference (CEFR) (2001) to assess their language proficiency. This framework is familiar to students from European universities (especially students who study languages) as it is the system that is used at their home universities to determine language proficiency. Several European universities base their language syllabi on the CEFR since it provides a basis whereby students can both assess themselves and be assessed by staff at tertiary institutions. 
After the discussion on the task-based approach, the focus of the article shifts to Mayer's (2009, 2011) cognitive theory of multimedia learning. This serves as the departure point for the second discipline on which this study is based, namely computer assisted language learning (CALL).

This theory provides the background for any activity designed for the computer. Mayer (2009) clearly states that no computer program should be supplied to learners without being designed according to a sound and empirically tested theory. The cognitive theory of multimedia learning provides this basis.

Following the description of the cognitive theory of multimedia learning, the emphasis in the article moves to the four design principles, developed by Mayer $(2009,2011)$. These are: the redundancy principle (people learn better from graphics and narration than from graphics, narration and printed text), the coherence principle (people learn better when unnecessary materials are excluded rather than included), the spatial contiguity principle (people learn better when corresponding words and pictures are placed close to each other) and the personalization principle (people learn better when the words in a multimedia presentation are more conversational and not in a formal style). The researchers then attempt to show how these two disciplines can be correlated. This is done by providing the results obtained from the completed questionnaires, as well as how one of these principles might be presented to students by means of a computer program.

Keywords: task-based language learning and teaching, needs analysis, computer assisted language learning (CALL), cognitive theory of multimedia learning

\section{Inleiding}

Die Nagraadse en Internasionale Kantoor (NGIK) van die Universiteit Stellenbosch is gestig met die doel om internasionale studente se leerervaring in Stellenbosch te koördineer en te fasiliteer. Een van die kursusse wat onder die NGIK se vaandel aangebied word, is Beginner Afrikaans Vlak I. Die doel van die kursus is onder meer om studente sosiale Afrikaans aan te leer. Studente volg die kursus vir een semester en het 4 ure 'n week vir 14 weke klas. Hierdie kursus is ' $n$ kredietdraende kursus en die studente verkry 12 Suid-Afrikaanse krediete vir die kursus.

Die studente wat vir hierdie kursus registreer is, het in die formele evaluering (wat aan die einde van elke kursus afgeneem word) die behoefte aan 'n rekenaarprogram, wat as 'n hersieningsprogram gebruik kan word, genoem. Die studente het ook tydens informele gesprekke met die navorsers aangetoon dat hulle almal 'n persoonlike rekenaar besit en van tegnologie in hulle alledaagse lewe en in hulle studies gebruik maak. Die navorsers het na aanleiding van dié gesprekke en die kommentaar in die formele evaluering besef dat die rol van tegnologie in die onderrig van die Beginner Afrikaans Vlak I-kursus daarom nie geïgnoreer kan word nie. Dit het aanleiding tot die breë studie gegee, waarvan in dié artikel slegs gedeeltelik verslag gelewer word. 
Nadat ondersoek ingestel is na verskeie onderrigbenaderings vir tweedetaalleer en -onderrig, soos desuggestopedia ${ }^{1}$ en die kommunikatiewe benadering ${ }^{2}$, het die enkele probleemgebiede in elke benadering geverg dat daar na alternatiewe benaderings gesoek moet word. Die vroeëre benaderings steun hoofsaaklik op 'n behavioristiese model vir leer en sien taal as linguistiese sisteme (fonologies, leksikaal en grammatikaal) wat misluk om taalaanleerders voor te berei op spontane, gekontekstualiseerde taalgebruik. Die navorsers is tans besig om die taakgebaseerde benadering tot leer en onderrig te ondersoek aangesien dit volgens internasionale navorsers soos Ellis (2003), Nunan (2004) en Skehan (1998) en plaaslike navorsers soos Kruger en Poser (2007), Steenkamp en Visser (2011) en Adendorff (2012) taalverwerwing die beste fasiliteer omdat dit die meeste geleenthede vir interaksie bied sodat betekenisonderhandeling effektief kan plaasvind.

In haar proefskrif ondersoek Adendorff (2012) die taakgebaseerde benadering met spesifieke fokus op kognitiewe kompleksiteit. Die breë studie wat onderneem word, is 'n verdere uitvloeisel daarvan. Die studie is 'n verkennende studie oor die moontlike ontwerp van 'n Afrikaanse taakgebaseerde rekenaaronderrigprogram vir internasionale studente aan die US, en ondersoek die gebruik van die rekenaar vir die aanleer en verwerwing van Afrikaans in hierdie kursus.

Die artikel poog om 'n bykomende bydrae te lewer tot navorsing wat die rol van rekenaargesteunde taalonderrigprogramme in tweedetaalverwerwing ondersoek en word deur die volgende vraag gelei: Hoe kan daar 'n moontlike verbintenis tussen 'n taakgebaseerde benadering en rekenaargesteunde taalonderrig (RGTO), spesifiek Mayer se multimediainstruksiebeginsels (sien afdeling 3.5) gemaak word? Dit sluit aan by artikels soos dié van Kruger (2007) en Steenkamp en Visser (2011) waarin juis hierdie onderwerp bespreek word.

\section{Taakgebaseerde benadering}

Tans word 'n Integrerende Kommunikatiewe Taalleer-benadering (IKT-benadering) in die Beginner Afrikaans Vlak 1-kursus gevolg. 'n IKT-benadering verwys na 'n benadering waar algemene taalleerteorieë met die kommunikatiewe benadering geïntegreer word om die student te bemagtig om binne ' $n$ korter tyd die taal te verwerf. Tog is daar in internasionale navorsing in die afgelope tyd 'n soeke na 'n meer teoretiese begronding vir die kommunikatiewe benadering, omdat soos Klapper (2003:32) tereg opmerk: "There seems to be little consensus on methodology, still less on the theoretical basis of this approach." Die navorsers het daarom besluit om die taakgebaseerde benadering te ondersoek.

Die taakgebaseerde benadering is 'n ontwikkeling binne die kommunikatiewe benadering met die belangrikste komponent die gebruik van take ${ }^{3}$ as metodologiese grondslag, maar ook as die

\footnotetext{
${ }^{1}$ Desuggestopedia is volgens Larsen-Freeman en Anderson (2011:71) 'n onderrigbenadering wat die studente help om emosies van mislukking te oorkom deur te fokus op die belangrikheid van desuggestie op studente se leerbeperkings.

${ }^{2}$ Berns (1990) noem twee aspekte van die kommunikatiewe benadering wat veral vir die Suid-Afrikaanse konteks van belang is, naamlik dat die benadering gebruik kan word vir sowel huistaalonderrig as addisioneletaalonderrig, en dat kultuur 'n belangrike rol speel in die ontwikkeling van kommunikatiewe bevoegdheid.

3 Take verwys na 'n betekenisdraende aktiwiteit wat soortgelyk is aan taalaanleerders se werklike kommunikasiebehoeftes. Volgens Adendorff (2012:412) is 'n taak "'n kommunikatiewe gebeurtenis met 'n nielinguistiese en/of linguistiese uitkoms".
} 
eenhede waarvolgens kursusse ontwerp word. Dit is 'n benadering tot taalverwerwing en taalonderrig wat rondom take georganiseer is en nie volgens taalstrukture nie.

Ellis (2003:9-10) omskryf ' $n$ taak in terme van ses kenmerkende eienskappe, naamlik dat dit 'n werkplan vir studente-aktiwiteite is, dat die primêre fokus op betekenis is, dat dit prosesse behels wat ooreenstem met werklikewêreld-taalgebruik, dat dit enige van die vier taalvaardighede (praat, lees, luister en skryf) insluit, dat dit 'n kognitiewe proses behels en dat dit duidelik definieerbare kommunikasie-uitsette het. Samuda en Bygate (2008:219) beklemtoon die feit dat take tot taalaanleer en -verwerwing kan bydra aangesien take as pedagogiese hulpmiddels in verskillende kontekste gebruik kan word. Die taakgebaseerde benadering is 'n pedagogie wat aansluit by die onderrigbeginsel "Leer deur te doen" (GonzálezLloret 2003:88). Rekenaargesteunde taalonderrig onderskryf dieselfde beginsel aangesien studente leer terwyl hulle besig is om die aanlyn-pedagogiese take te doen.

Binne die taakgebaseerde benadering is werklikewêreld-take (of teikentake) die uitgangspunt in die ontwerp van 'n taakgebaseerde sillabus. Die beplanning van 'n taakgebaseerde sillabus sluit prosedures in waarvan die eerste die identifisering van taalaanleerders se behoeftes is.

As eerste stap in die ontwerp van 'n taakgebaseerde sillabus moet daar volgens Brown (2009:269), Robinson (2009:302), Duran en Ramaut (2006) en Van Avermaet en Gysen (2006) 'n behoefte-analise gedoen word. Adendorff (2012:60) omskryf 'n behoefte-analise as die sistematiese bymekaarmaak en analise van al die subjektiewe en objektiewe, asook enige ander, inligting wat nodig is om 'n verdedigbare kurrikulum te beskryf.

Die doel van die behoefte-analise wat vir die artikel onderneem is, dien as basis vir die ontwerp van 'n taakgebaseerde sillabus wat in die kursus Beginner Afrikaans Vlak 1 toegepas sal word. Verder dien dit as basis vir die ontwerp van 'n rekenaaronderrigprogram wat in hierdie nuutontwerpte taakgebaseerde sillabus gebruik sal word.

\section{Die kognitiewe teorie van multimedia-leer}

Die rol van die rekenaar binne 'n Afrikaanse taalverwerwingsklas, wat 'n ander dimensie van onderrigmoontlikhede na vore bring, word verder in hierdie artikel ondersoek. Take op die rekenaar kan nie net lukraak ontwerp word en aan studente verskaf word nie, daarom is die kognitiewe teorie van multimedia-leer ondersoek om te sien of dit versoenbaar is met die taakgebaseerde benadering tot leer en onderrig aangesien dit ook 'n kognitiewe taalleer en taalonderrigbenadering is. Aangesien rekenaarprogramme ruimte vir klank, prente en animasie laat, pas dit vir die navorsers goed by die verskillende leerstyle van die studente (sien afdeling 3.5.1) aangesien $69 \%$ van die studente gesê het hulle hou daarvan om met prente en woorde te leer.

Die rasionaal vir multimedia-leer berus op die beginsel dat mense meer diepte in hulle leer ervaar wanneer hulle woorde en prente sien as net woorde alleen, maar om net grafika, prente of animasie by woorde te plaas, beteken nie dat studente se leer gaan verbeter nie. Hierdie beginsel, wat die multimedia-beginsel ("multimedia principle") genoem word, is volgens Mayer (2010) verantwoordelik vir die belangstelling in multimedia-leer. 
Ten einde te verstaan hoe om woorde en prente in die rekenaarprogram te gebruik sodat leer kan verbeter, is dit belangrik om Mayer (2001:32) se fundamentele hipotese tot multimedialeer te noem: Multimedia-instruksieboodskappe en -take wat ontwerp is aan die hand van hoe die mens se brein werk, kan moontlik tot meer betekenisvolle leer lei as instruksieboodskappe en take wat nie daarvolgens ontwerp is nie. Op die vraag: "Wat is 'n multimediainstruksieboodskap?" verskaf Mayer (2001:32) die volgende omskrywing, naamlik dat dit kommunikasie is wat woorde en prente bevat wat bedoel is om leer te bevorder. Dit sluit handboeke en aanlynlesse wat animasie bevat, in.

Die kognitiewe teorie van multimedia-leer verduidelik die proses vir die ontwerp van 'n rekenaarprogram sodat oorlading van die aandagsbronne nie plaasvind nie. Die teorie word in figuur 1 opgesom.

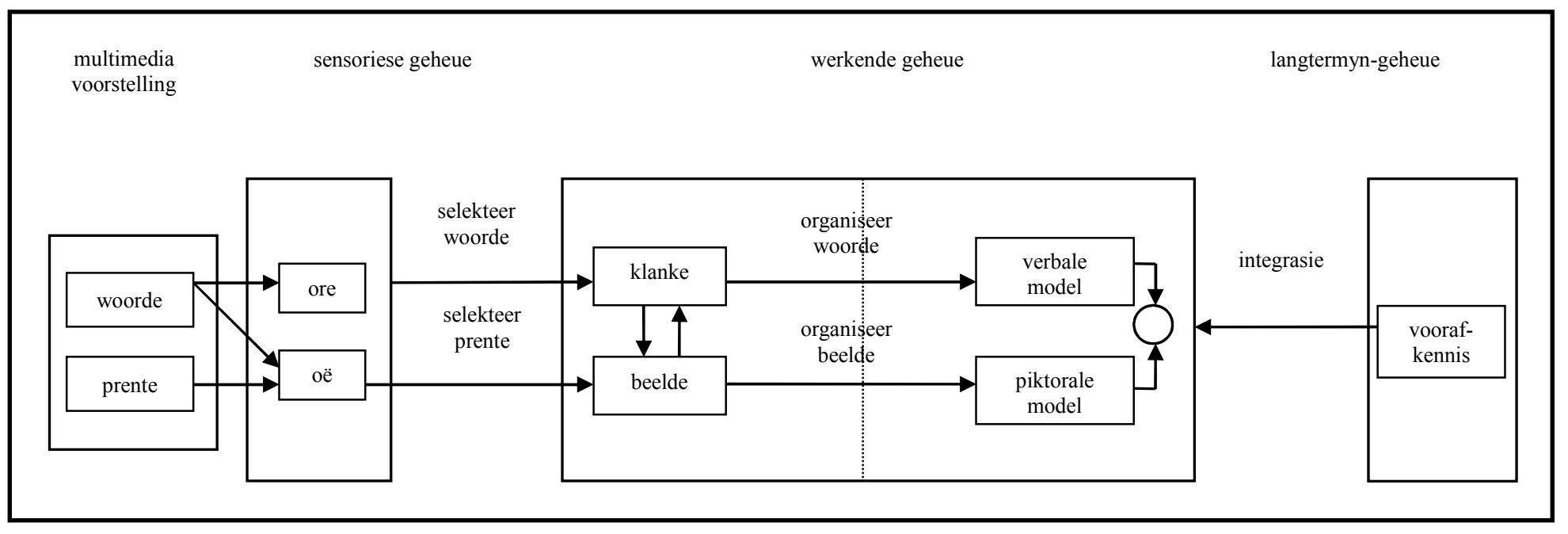

Figuur 1: Die kognitiewe teorie van multimedia-leer

Bogenoemde teorie word voorts aan die hand van drie onderliggende aannames, drie geheuestore, vyf kognitiewe prosesse en vyf voorstellingsvorme verduidelik.

\subsection{Drie aannames van die kognitiewe teorie van multimedia-leer}

Die ontwerp van multimedia-instruksieboodskappe word direk deur die ontwerper se idees van hoe die mens se brein werk, beïnvloed. Wanneer 'n multimedia-voorstelling bestaan uit 'n skerm vol gekleurde woorde en prente wat rondbeweeg en flits, reflekteer dit die ontwerper se konsep van hoe mense leer. Die ontwerper van bogenoemde voorstelling se onderliggende konsep is dat studente 'n enkel-prosesseringskanaal het, onbeperkte kapasiteit het en oor 'n passiewe prosesseringsisteem beskik. Volgens Mayer (2001) weerspreek huidige navorsing in kognitiewe sielkunde hierdie siening. Die drie aannames van die kognitiewe teorie van multimedia-leer is die tweeledige kanaal-aanname, die beperkte kapasiteitsaanname en die aktiewe prosesseringsaanname.

\subsubsection{Die tweeledige kanaal-aanname (“dual channel assumption")}

Hierdie aanname veronderstel dat mense oor aparte informasieprosesseringskanale beskik. Een kanaal prosesseer visuele materiaal en die ander kanaal prosesseer ouditiewe materiaal. Die 
kognitiewe teorie van multimedia-leer verklaar dat die menslike inligtingsprosesseringsisteem 'n ouditiewe/verbale kanaal en 'n visuele/piktorale kanaal bevat. Wanneer inligting aan die oë (deur middel van prente of animasie) voorgestel word, begin mense om daardie inligting in die visuele kanaal te prosesseer. Wanneer inligting aan die ore voorgestel word (deur middel van vertellings of nieverbale klanke) begin die prosessering in die ouditiewe kanaal.

\subsubsection{Die beperkte kapasiteitsaanname ("limited capacity assumption")}

Die tweede aanname is deur Van Merrienboer (1997) en Sweller (2005) ondersoek. Hulle het gevind dat prosessering wat binne elke informasieprosesseringskanaal plaasvind uiters beperk is. Hierdie beperkings op studente se prosesseringskapasiteit forseer hulle om te besluit watter inkomende inligting aandag moet geniet. Dit bepaal in hoe 'n mate die student verbindings tussen die geselekteerde stukke inligting gaan maak, asook die mate van verbindings tussen die stukke inligting en die student se bestaande kennis.

\subsubsection{Die aktiewe prosesseringsaanname ("active processing assumption")}

Die laaste aanname is spesifiek deur Mayer $(2001,2009,2011)$ ondersoek. Hierdie aanname vind dat betekenisvolle leer plaasvind wanneer studente in aktiewe kognitiewe prosesse betrokke is. Wanneer studente aandag aan relevante inkomende woorde en prente gee, dit kognitief organiseer en dit integreer met hulle voorafkennis, word hierdie proses nog verder versterk. Die proses van aktiewe prosessering gee dus aanleiding tot betekenisvolle leer en kan die oordra van probleemoplossing ondersteun. Daar is drie prosesse wat belangrik is vir aktiewe leer. Die prosesse is die keuse van relevante materiaal, die organisering van hierdie materiaal en die integrasie van hierdie materiaal met die bestaande kennis. Vervolgens word die drie geheuestore bespreek.

\subsection{Drie geheuestore in multimedia-leer}

Figuur 1 verteenwoordig die kognitiewe teorie van multimedia-leer waarin mense se informasieprosesseringsisteem verteenwoordig word. Dit sluit die sensoriese geheue, die werkende geheue en die langtermyngeheue in. Multimedia-voorstellings in die vorm van prente en woorde kom van die buitewêreld in. Dit gaan dan in die sensoriese geheue in deur middel van die oë of die ore. Die pyltjie van "prente" na "oë" dui aan wanneer 'n prent in die oë geregistreer word. Die pyltjie van "woorde" na "ore" dui aan wanneer gesproke teks in die ore geregistreer word. Die pyltjie van "woorde" na "oë" dui aan wanneer gedrukte teks in die oë geregistreer word. Mayer (2011) noem dat die sensoriese geheue net vir 0,25 sekondes 'n presiese weergawe van die inligting wat die geheue binnekom, hou.

Die sentrale werk ten opsigte van multimedia-leer vind in die werkende geheue plaas. Hierdie geheue word gebruik om kennis tydelik te stoor en te verwerk. Die linkerkant van die "werkende geheue"-blokkie verteenwoordig die rou materiaal wat die geheue binnekom. Die regterkant van die "werkende geheue"-blokkie verteenwoordig die kennis wat in hierdie geheue saamgestel is. Die pyltjie van "klanke" na "beelde" verteenwoordig die omskakeling van 'n klank (byvoorbeeld die woord "kat") na 'n visuele beeld (byvoorbeeld 'n prentjie van 'n kat). Studente kan dus die woord "kat" hoor en 'n visuele voorstelling van 'n kat in hulle brein vorm. Die proses kan omgekeerd werk. Wanneer studente 'n prent van 'n kat sien, mag hulle dalk die woord "kat" verbaal sê of onthou hoe die woord in die voorstelling geklink het. 
Die belangrikste kognitiewe prosesse wat vir multimedia-leer benodig word, word deur die pyltjies by "selekteer prente", "selekteer woorde", "organiseer beelde", "organiseer woorde" en "integrasie" aangedui. Hierdie prosesse word in afdeling 3.3 bespreek.

Die blokkie aan die regterkant verteenwoordig die langtermyngeheue. Hierdie geheue verskil van werkende geheue omdat dit groot hoeveelhede kennis vir lang tydperke kan behou. As mense aktief oor materiaal wil dink, moet dit weer na die werkende geheue herroep word. Dit is dan wat die pyltjie van "langtermyngeheue" na "werkende geheue" aandui.

\subsection{Vyf prosesse in die kognitiewe teorie van multimedia-leer}

Mayer $(2001,2009,2011)$ beskryf vyf kognitiewe prosesse wat in multimedia-omgewings aanwesig moet wees. Hierdie prosesse veroorsaak dat betekenisvolle leer plaasvind. Alhoewel die prosesse hieronder puntsgewys bespreek word, beteken dit nie dat dit in liniêre volgorde gebeur nie. Studente kan op verskeie maniere van proses tot proses beweeg solank die prosesse deur die student gekoördineer en gemonitor word.

\subsubsection{Selektering van relevante woorde}

Die eerste onderafdeling in figuur 1 behels die verandering van die eksterne voorstelling van gesproke woorde (byvoorbeeld 'n rekenaarontwerpte vertelling) na 'n sensoriese verteenwoordiging van klanke en dan na ' $n$ verteenwoordiging van woordklanke binne-in die interne werkende geheue (byvoorbeeld sommige woorde in die vertelling). Die inset vir hierdie stap is 'n gesproke verbale boodskap - met ander woorde die gesproke woorde in die multimedia-boodskap. Die uitkoms is dat studente mentale (brein) voorstellings van sekere woorde en frases binne hulle verbale werkende geheue sal mak. Die kognitiewe proses wat hierby betrokke is, is die selektering van relevante woorde. Tydens hierdie proses gee studente aandag aan sekere woorde binne die multimedia-boodskap terwyl dit deur die ouditiewe sensoriese geheue gaan. As die woorde as spraak aangebied word, sal die proses in die ouditiewe kanaal begin. Dit word deur die pyltjies van "woorde" na "ore" na "klanke" aangedui. As die woorde op die skerm verskyn of as gedrukte teks aangebied word, begin die proses in die visuele kanaal. Hierdie proses word deur die pyltjie van "woorde" na "oë" aangedui. Volgens Mayer (2001:39) kan hierdie proses na die ouditiewe kanaal toe beweeg wanneer die student dalk die woorde in hulle gedagtes herhaal. Die pyltjie wat van "beelde" na "klanke" toe beweeg in die linkerkant van werkende geheue dui hierdie proses aan. Soos reeds genoem, het elke kanaal 'n beperkte kapasiteit en kan die studente net gedeeltes van die materiaal stoor. Die seleksie van woorde geskied nie lukraak nie. Die student moet self besluit watter woorde relevant is. Hierdie siening is konsekwent met die siening dat die student ' $n$ aktiewe deelnemer aan leer is en self sin maak van die inligting.

\subsubsection{Selektering van relevante prente}

Die eksterne voorstelling van prente (soos byvoorbeeld ' $n$ illustrasie of ' $n$ animasie) verander na 'n sensoriese voorstelling van visuele beelde en dan na ' $n$ interne voorstelling binne-in die werkende geheue. Die inset vir hierdie stap is 'n visuele gedeelte van 'n multimediavoorstelling wat vir 'n kort periode in die werkende geheue gestoor word. Die uitkoms vir hierdie stap is 'n visuele beeld-basis (dit word "beelde" in figuur 1 genoem). Die student vorm 'n mentale (brein) voorstelling van geselekteerde beelde binne-in hulle werkende geheue. 
Mayer (2010:546) noem hierdie kognitiewe proses die selektering van relevante prente. Die proses behels dat aandag aan sekere gedeeltes van 'n animasie of illustrasie gegee word. Die proses begin in die visuele kanaal, maar dit is ook moontlik dat ' $n$ gedeelte na die ouditiewe kanaal verander kan word. Weereens moet die student 'n seleksie maak omdat die kognitiewe sisteem beperk is. Die proses vind nie lukraak plaas nie en die student moet spesifiek kies watter gedeeltes relevant is.

\subsubsection{Organisering van geselekteerde/gekose woorde}

As die studente klaar 'n basis van woorde gevorm het, moet hierdie woorde in 'n koherente voorstelling georganiseer word. Mayer (2001:40) noem hierdie struktuur van kennis 'n verbale model. Die inset vir hierdie stap is die basis van woorde wat deur die student gekies is. Die uitkoms is 'n verbale model. Met ander woorde die gekose woorde of frases word georganiseer binne-in die student se werkende geheue. Die kognitiewe proses wat betrokke is by hierdie verandering is die organisering van geselekteerde/gekose woorde. Tydens hierdie proses vorm die student verbindings tussen gedeeltes van verbale kennis. Die proses gebeur in die ouditiewe kanaal en is onderhewig aan die beperkings van die kognitiewe sisteem soos vroeër genoem (sien afdeling 3.1).

\subsubsection{Organisering van geselekteerde/gekose beelde}

Die proses vir die organisering van beelde geskied op dieselfde manier as wat sopas beskryf is. Wanneer die student klaar ' $n$ basis van visuele beelde gevorm het, moet hierdie beelde in 'n koherente voorstelling georganiseer word. Mayer (2001:40) noem hierdie struktuur 'n piktorale model. Die inset vir hierdie stap is die basis van woorde wat deur die student gekies is. Die uitkoms is 'n gestruktureerde voorstelling van beelde in die student se werkende geheue. Dit word as die piktorale model in figuur 1 uitgebeeld. Hierdie verandering van beelde na die piktorale model word die organisering van geselekteerde/gekose beelde genoem. Vergelykings tussen gedeeltes van beelde word gevorm en dit geskied in die visuele kanaal. Dieselfde beperkings op die kognitiewe sisteem geld ook in hierdie proses (sien afdeling 3.1) Die studente bou dus kousale verbindings waar die een gebeurtenis aanleiding gee tot die volgende gebeurtenis.

\subsubsection{Die integrasie van woord- en prentgebaseerde voorstellings}

Hierdie stap is moontlik die heel belangrikste in multimedia-leer. In hierdie stap moet daar verbindings tussen woordgebaseerde en prentgebaseerde voorstellings gemaak word. Daar moet nou van twee aparte voorstellings (die verbale model en die piktorale model) na een geïntegreerde voorstelling beweeg word. Die inset vir hierdie stap is die twee modelle wat die student sover gevorm het. Die uitkoms is 'n geïntegreerde model wat op die verbindings tussen die twee modelle gebaseer is. Die geïntegreerde model het ook 'n verbinding met die student se voorafkennis. Mayer (2001:40) verwys na hierdie kognitiewe proses as die integrasie van woorde en beelde. Die proses geskied binne-in die visuele en verbale werkende geheue en behels koördinasie tussen hierdie gedeeltes. Dié proses stel hoë kognitiewe eise en die kognitiewe kapasiteit moet effektief gebruik word. Studente kan hulle voorafkennis gebruik om hierdie integrasieproses te koördineer - die pyltjie van "langtermyngeheue" na "werkende geheue" dui die proses aan. Tabel 1 verskaf opsommend bogenoemde vyf kognitiewe prosesse. 
Elkeen van die vyf prosesse kan heel moontlik meer as een keer tydens multimedia-leer plaasvind.

Tabel 1: Vyf kognitiewe prosesse in die kognitiewe teorie van multimedia-leer

\begin{tabular}{|l|l|}
\hline Proses & Beskrywing \\
\hline Selektering van woorde & $\begin{array}{l}\text { Studente gee aandag aan relevante woorde binne-in 'n multimedia- } \\
\text { boodskap en skep klanke in die werkende geheue. }\end{array}$ \\
\hline Selektering van prente & $\begin{array}{l}\text { Studente gee aandag aan relevante prente binne-in 'n multimedia- } \\
\text { boodskap en skep beelde in die werkende geheue. }\end{array}$ \\
\hline Organisering van woorde & $\begin{array}{l}\text { Studente maak verbindings tussen geselekteerde woorde om 'n verbale } \\
\text { model in werkende geheue te vorm. }\end{array}$ \\
\hline Organisering van beelde & $\begin{array}{l}\text { Studente maak verbindings tussen geselekteerde prente om 'n piktorale } \\
\text { model in werkende geheue te vorm. }\end{array}$ \\
\hline Integrasie & $\begin{array}{l}\text { Studente maak verbindings tussen die verbale model, die piktorale } \\
\text { model en hulle voorafkennis. }\end{array}$ \\
\hline
\end{tabular}

\subsection{Die vyf voorstellingsvorme}

Soos in figuur 1 gesien kan word, is daar vyf voorstellingsvorme vir woorde en prente soos wat hulle deur die verskillende stadiums van prosessering beweeg. Aan die heel linkerkant van die figuur is daar woorde en prente in die multimedia-voorlegging. Hierdie woorde en prente vorm die stimulus wat aan die student gebied word. Tweedens, word die prent en woorde aan die student se ore en oë blootgestel. Daar word klanke of beelde in die sensoriese geheue gevorm. Hierdie sensoriese voorstelling vervaag gou as die student nie aandag daaraan gee nie. Wanneer die student aandag aan die woorde en klanke gee, word daar derdens 'n seleksie gemaak wat verdere aandag binne-in die werkende geheue sal kry. Sorden (2005) noem dat hierdie fase deur die klanke en beelde in die werkende geheue voorgestel word. Hierdie proses verskaf die bousteen vir die konstruksie of bou van kennis. Vierdens, word 'n verbale model en 'n piktorale model in die werkende geheue gevorm. Die student het nou tydens hierdie gedeelte die materiaal in koherente voorstellings georganiseer. Die laaste vorm van representasie of voorstelling is die kennis in die langtermyngeheue. Die student gebruik hierdie proses om die opbou van kennis in die werkende geheue te begelei. Nadat kennis in die werkende geheue opgebou is, word dit in die langtermyngeheue as voorafkennis gestoor. Dit word dan gebruik om nuwe leerervarings te ondersteun. Tabel 2 verskaf 'n opsomming van bogenoemde.

Tabel 2: Vyf voorstellingsvorme in die kognitiewe teorie van multimedia-leer

\begin{tabular}{|l|l|}
\hline Kennistipes & Plek \\
\hline Woorde en prente & Multimedia-voorstelling \\
\hline Akoestiese en ikoniese voorstellings & Sensoriese geheue \\
\hline Klanke en beelde & Werkende geheue \\
\hline Verbale en piktorale modelle & Werkende geheue \\
\hline Voorafkennis & Langtermyngeheue \\
\hline
\end{tabular}

\subsection{Multimedia-instruksiebeginsels}

Om 'n meer praktiese benadering tot sy teorie te verskaf, het Mayer (2009) onder andere die volgende vier multimedia-instruksiebeginsels geïdentifiseer om die effek daarvan op onderrig te toets. Die beginsels word vervolgens bespreek en daarna word 'n praktiese voorbeeld uit die 
rekenaarprogram wat tans ontwikkel word, verskaf. Die vier instruksiebeginsels is: die oortolligheidseffek, die samehangeffek, die ruimtelike-aangrensingseffek en die verpersoonlikingseffek.

Mayer (2009) voer in die oortolligheidseffek aan dat studente beter leer wanneer daar prente en vertellings is, as wanneer daar prente, vertellings en gedrukte teks is.Volgens Kruger (2007) verwys die samehangeffek daarna dat studente beter leer wanneer die onderrigmateriaal betekenisvol is en inligting uitsluit wat nie relevant is nie. Mayer (2001:133) stel dit duidelik dat onverwante inligting met die studente se aandagspan kan inmeng. Die kousale verbandsketting (wat in die organiseringsproses gevorm word) kan sodoende onderbreek word.

Die kern van die ruimtelike-aangrensingseffek is gegrond op die beginsel dat ooreenstemmende woorde en prente naby mekaar op die skerm moet verskyn in plaas van ver uitmekaar (Kruger 2007:23). Hierdie effek steun op die student se werkende geheue. Dit bevorder ook die proses waardeur visuele en verbale modelle deur die student geïntegreer word - dit is 'n kernaspek in aktiewe leer.

Die verpersoonlikingseffek stel dit duidelik dat studente se leer dieper is wanneer die woorde in 'n multimedia-voorstelling nie formeel aangebied word nie, maar meer op 'n gesprekstyl. Met ander woorde 'n meer informele styl van woorde word verkies. Hierdie effek veroorsaak dat studente voel dat hulle in 'n mens-tot-mens gesprek is en so die kommunikasieskema bevorder (Mayer 2011). Studente mag dus deurdat hulle die verpersoonlike boodskappe probeer verstaan, besig wees om hierdie inligting te organiseer en te integreer.

\subsubsection{Integrasie van die taakgebaseerde benadering en Mayer se multimedia- instruksiebeginsels}

Vervolgens word 'n verbinding tussen die taakgebaseerde benadering en die instruksiebeginsels wat Mayer voorstel, gemaak.

As deel van die behoefte-analise wat die studente onderneem het, is 'n vraelys met 'n kombinasie van oop en geslote vrae opgestel en aan die begin van die kursus onder al die studente versprei. Die vraelys het vier vrae aan die studente gevra en gefokus op die rede waarom hulle ingeskryf het vir die kursus, hulle leerstyl, hulle taalvaardigheidsvlak volgens die Europese Referensiekader (ERK) en laastens onderwerpe wat hulle graag in die klas behandel wil hê.

Die studente wat vir die kursus Beginner Afrikaans Vlak I inskryf, kom vanuit verskillende lande en vastelande en toon daarom 'n diverse profiel. Figuur 2 verskaf 'n diagrammatiese voorstelling van die verspreiding van studente vir die tweede semester van 2013. 


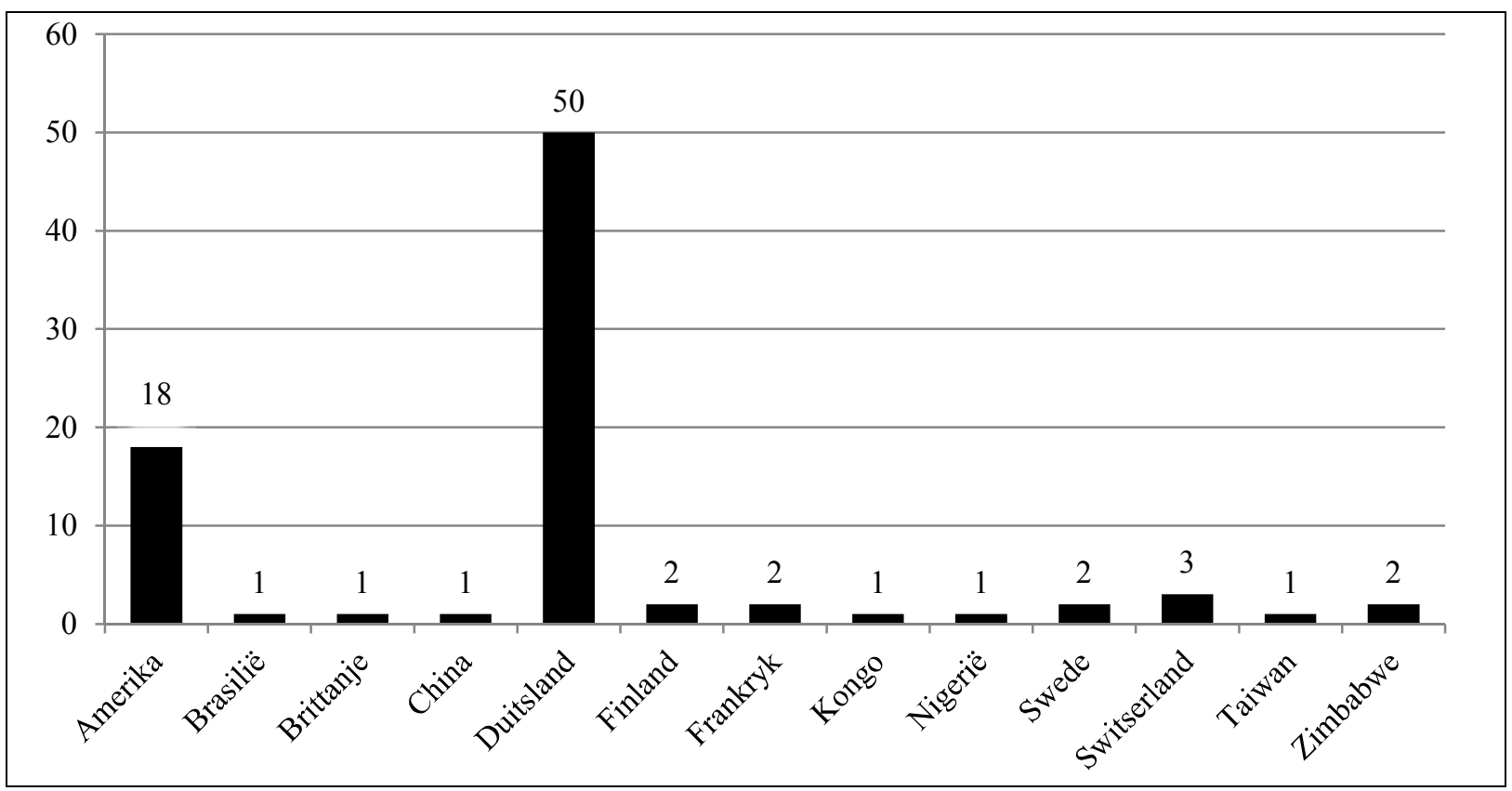

Figuur 2: Studenteverspreiding vir die kursus Beginner Afrikaans vlak $1(\mathrm{n}=85)$

Figuur 3 verskaf vervolgens 'n aanduiding van watter vastelande die studente wat die kursus volg, kom. Soos gesien kan word, kom die studente wat vir die kursus inskryf van Europa (61 studente), asook Amerika (18 studente), Afrika (4 studente) en Asië (2 studente).

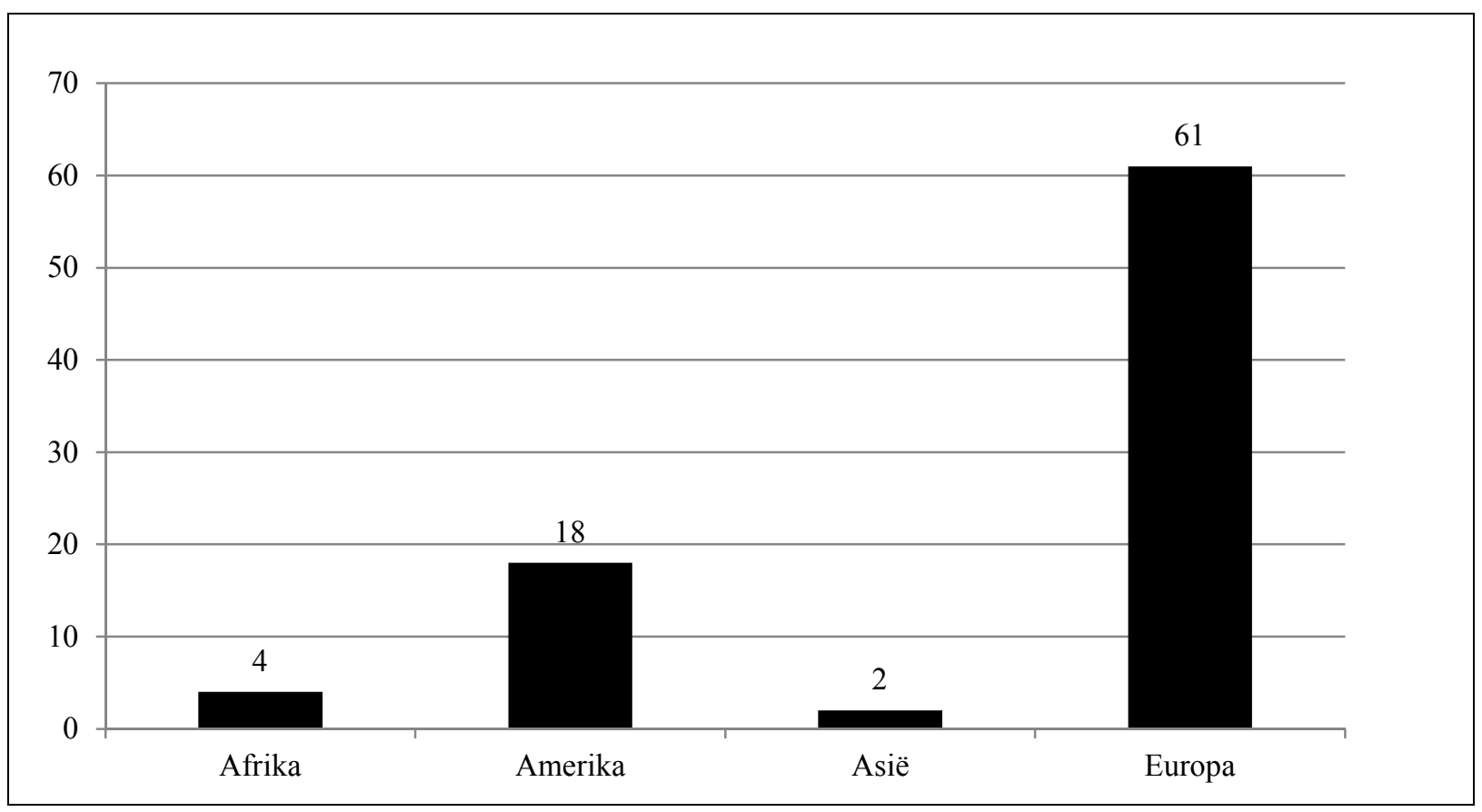

Figuur 3: Studenteverspreiding volgens vastelande $(\mathrm{n}=85)$

Dit is duidelik uit bostaande data dat hierdie klas 'n diverse studenteprofiel toon, aangesien studente vanuit 13 verskillende lande en vier kontinente vir die kursus ingeskryf het. Die studente het nog nooit voorheen met Afrikaans kontak gehad nie en is beginnersprekers van Afrikaans. 
Tydens aktiwiteite word daar probeer om sover as moontlik studente van verskillende bevolkingsgroepe saam te groepeer. Dit gee die studente kans om van en oor mekaar en mekaar se kulture te leer. 'n Verskuilde doelwit in tweedetaalonderrig (ook so met dié kursus) is om meer te leer van die kultuur van die taal wat aangeleer word. Die studente dui telkens tydens informele terugvoersessies, asook met die formele assesseringsgeleentheid (wat aan die einde van die kursus gedoen word) aan hoe hulle die interaksie tussen die verskillende bevolkingsgroepe geniet, en ervaar dit as baie positief.

Die vraelys het eerstens aan studente gevra waarom hulle die kursus neem. Die onderstaande reaksies is sommige van die antwoorde wat van die studente gekry is:

"Understanding a language is a large part of understanding the people and culture."

"Learning Afrikaans will help with my understanding and add to my appreciation thereof."

"Language is the key to understanding a culture."

"I want to be able to speak Afrikaans."

"It is easier to take part in the culture of South Africa if you understand Afrikaans."

Uit bogenoemde redes kan die afleiding gemaak word dat studente die waarde vir die aanleer en verwerwing van 'n taal, wat toegang tot die kultuur van die sprekers daarvan verleen, verstaan.

Twee ander reaksies wat deur die studente genoem word, moet gemeld word. Dit dui daarop dat daar beslis ook bymotiewe in die leer van 'n taal is!

"To understand my boyfriend's parents."

"To be able to pick up beautiful South African girls!"

Die vraelys het tweedens vir studente gevra om hulle verskillende leerstyle ${ }^{4}$ (sien figuur 4 ) aan te dui. Hierdie vraag gee 'n duideliker en meer akkurate aanduiding van die tipe take wat op die rekenaar ontwerp behoort te word en of die fokus daarvan meer ouditief of visueel behoort te wees. Dit dien as uitgangspunt in die ontwerp van die rekenaarprogram, omdat die rekenaar juis ruimte vir visuele en ouditiewe stimuli laat.

Die resultate oor die leerstyle het daarop gedui dat $69 \%$ van die studente eerstens verkies om woorde en prente te sien wanneer hulle leer. In die tweede plek het $53 \%$ van die studente aangedui dat hulle daarvan hou om interaktief met die taal om te gaan.

\footnotetext{
${ }^{4}$ Studente kon meer as een opsie onder hierdie vraag kies, en daarom is die persentasies nie gelyk aan $100 \%$ nie.
} 


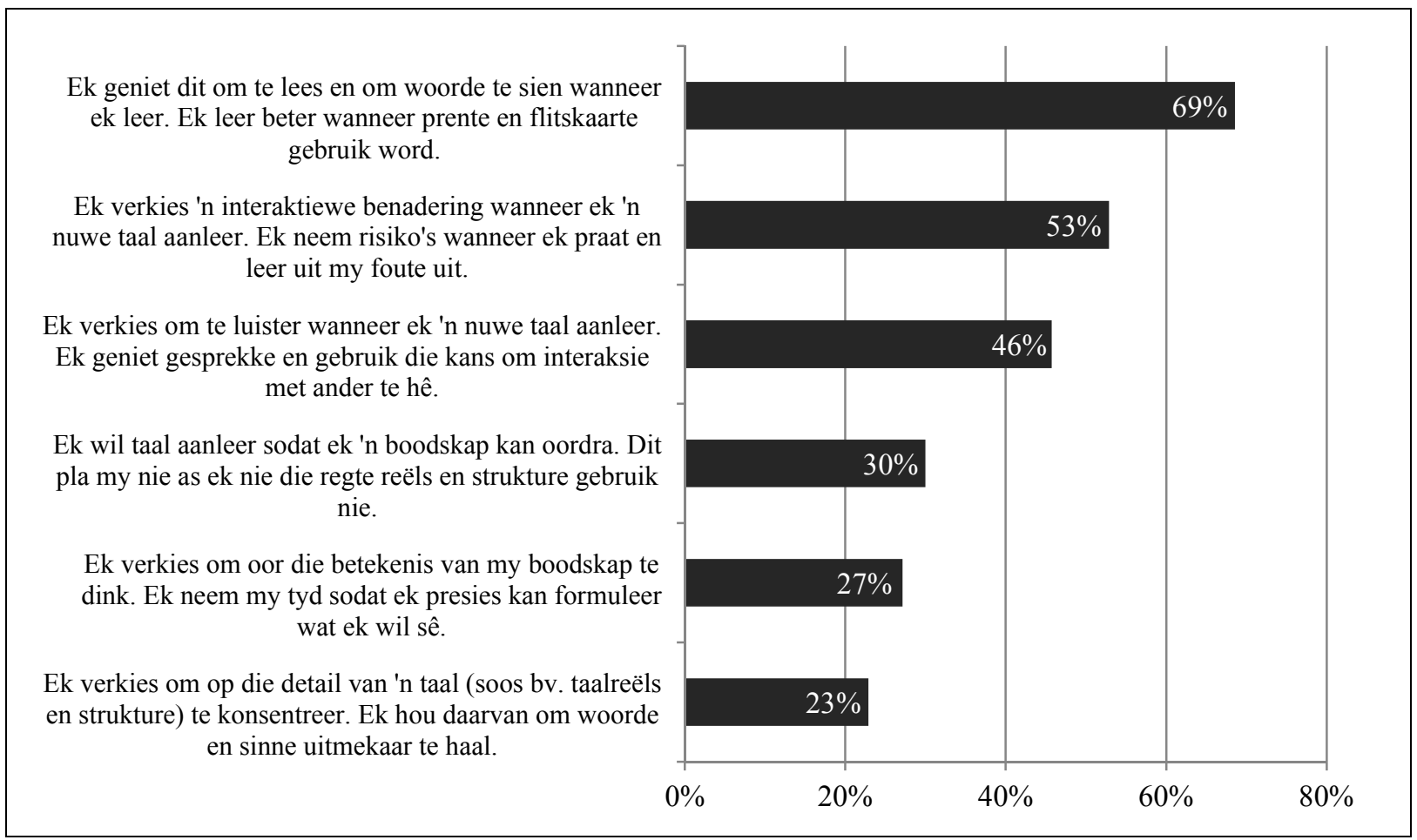

Figuur 4: Studente se verskillende leerstyle

Die studente moes derdens hulle Afrikaanse taalvermoë evalueer deur van die Europese Referensiekader (2001) se self-analitiese tabel gebruik te maak wat die vaardigheidvlakke ten opsigte van verskeie tale in Europa aandui. Die rede vir die gebruik van die ERK is om die studente as taalgebruikers met spesifieke taalbehoeftes te sien wat met die taal in regtewêrelddomeine moet kan funksioneer, soos wat North (2014) aanbeveel. Die ERK bied aan taalonderwysers 'n beginpunt om taalaanleerders se werklikewêreld-taalvaardighede te meet. Die meeste studente het hulle as A1 by al die onderafdelings van praat, lees en skryf geklassifiseer. Dit beteken dat die studente hulleself as basiese gebruikers (die A1-vlak) van Afrikaans op die ERK beskou.

Volgens Duran en Ramaut (2006:49) en Van den Branden (2006) is een van die uitkomstes van behoefte-analises om lyste taalleerdoelwitte te formuleer. Die vraelys het daarom vierdens gevra dat studente onderwerpe wat hulle die graagste in die klas behandel wil hê, moes lys om sodoende te kan bepaal wat hulle taalleerdoelwitte is. Hierdie vrae is spesifiek gevra omdat behoefte-analises volgens Samuda en Bygate (2008:54) gebruik word om taalaanleerders se behoeftes in die werklike lewe te bepaal sodat taalkursusse rondom die behoeftes ontwerp kan word aangesien dit duidelik is wat die taalaanleerders se taalleerdoelwitte is. Die uitslae van hierdie vraag was as volg:

1 Bestel kos in 'n restaurant.

2 Bespreking van naweekplanne.

3 Vra raad oor plekke wat in Suid-Afrika besoek kan word.

$4 \quad$ Koop produkte by supermarkte en ander winkels.

5 Verstaan verkeerstekens en vra vir rigting.

6 Praat oor stokperdjies. 
$7 \quad$ Bespreek gunstelingflieks en akteurs en aktrises.

8 Praat oor spesifieke huisvesting waarin studente kan bly.

Een van bogenoemde onderwerpe is gekies en ' $n$ instruksiebeginsel is daaraan gekoppel om te illustreer hoe dit moontlik in die rekenaarprogram gebruik kan word.

Die onderwerp "Rigting" (nommer 5 op die bostaande lys) is gekies, en die ruimtelikeaangrensingseffek word daaraan gekoppel om prakties te illustreer hoe dit op die rekenaar ontwerp kan word. 'n Spesifieke taalstruktuur word ook aan die oefening gekoppel sodat die multimedia-voorstelling weer terugskakel met die taakgebaseerde benadering. Daar is besluit om die taalstruktuur "voorsetsels" aan bogenoemde multimedia-voorstelling te koppel.

Studente word in twee groepe gedeel ('n groep A en groep B op grond van lukrake indeling deur die dosent). Die groepe ontvang presies dieselfde prente en teks, maar die verskil is dat Groep A se prente en teks naby mekaar op die skerm vertoon gaan word en groep B se prente en teks ver van mekaar. Die voorbeelde word in figuur 5 en 6 hieronder aangedui.
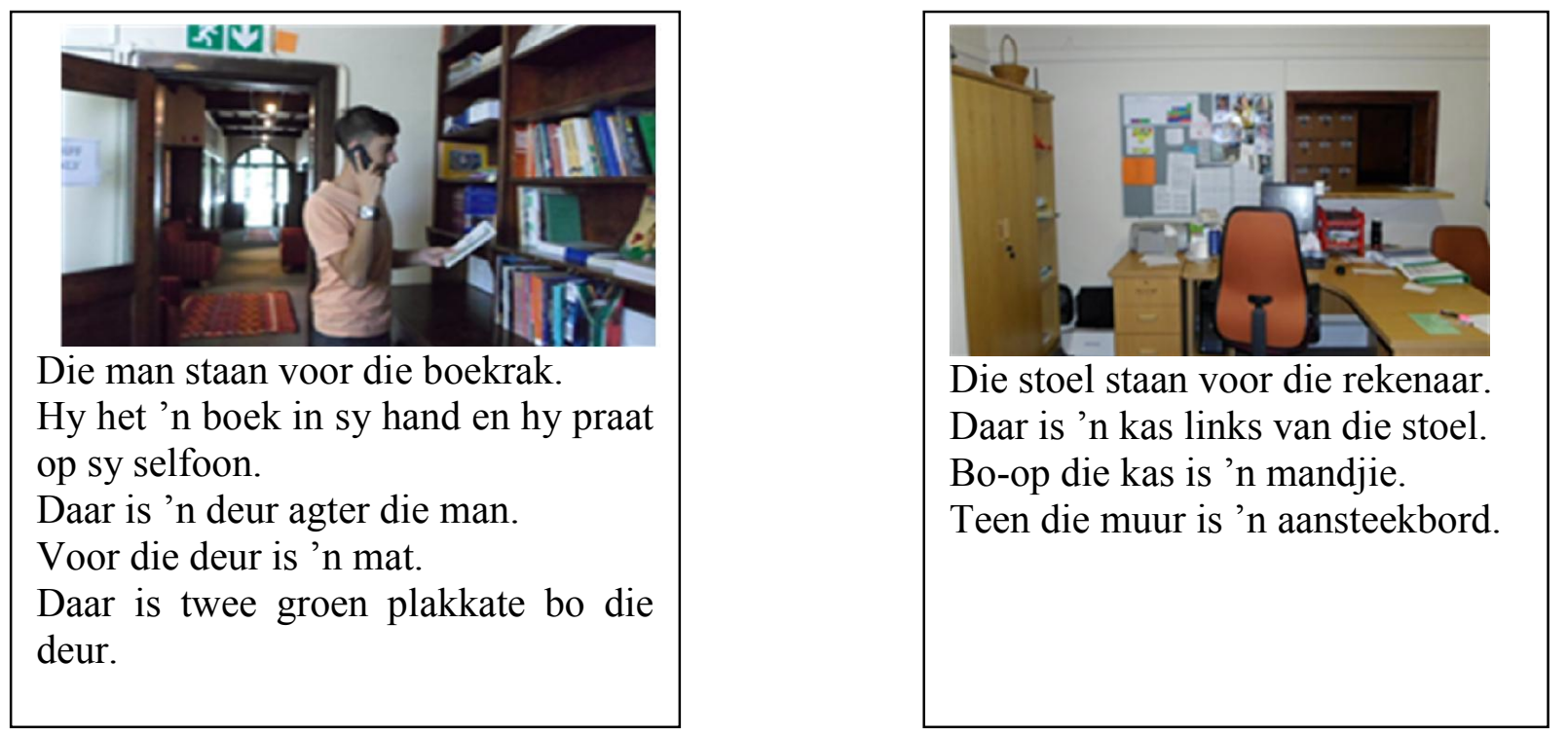

Figuur 5: Groep A: prente en teks is bymekaar op die skerm

Die man staan voor die boekrak.

Hy het 'n boek in sy hand en hy praat op sy selfoon.

Daar is 'n deur agter die man.

Voor die deur is 'n mat.

Daar is twee groen plakkate bo die deur.

Die stoel staan voor die rekenaar.

Daar is 'n kas links van die stoel.

Bo-op die kas is 'n mandjie.

Teen die muur is 'n aansteekbord.

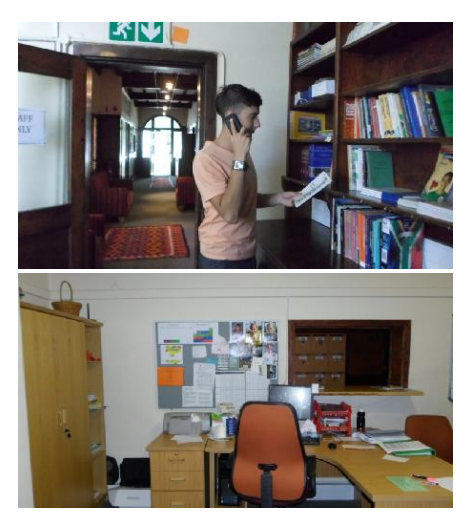

Figuur 6: Groep B: prente en teks is ver van mekaar op die skerm 
Aangesien die taalstruktuur wat aan die onderwerp gekoppel is, voorsetsels is, ontvang die studente as 'n tweede taak 'n vereenvoudigde kaart en moet die volgende vrae beantwoord:

\section{Is die sinne waar of vals?}

- Die polisie is links van die sportgronde.

$\mathrm{W} / \mathrm{V}$
$\mathrm{W} / \mathrm{V}$
$\mathrm{W} / \mathrm{V}$
$\mathrm{W} / \mathrm{V}$

- Perlemoenstraat is regs van Kusweg.

- Die hospitaal is bo die sportgronde

Laastens word 'n oop vraag aan die studente gestel sodat hulle begrip van die teks getoets kan word, met ander woorde, het hulle die inhoud verstaan. Die doel met hierdie vraag is voorts of die studente onafhanklik en selfstandig kan reageer op die vraag.

Die res van die multimedia-voorstellings is tans besig om ontwikkel te word en daar sal in ' $\mathrm{n}$ volgende artikel meer breedvoerig hieroor verslag gelewer kan word.

Bogenoemde oefening illustreer hoe die taakgebaseerde benadering en die kognitiewe teorie van multimedia-leer bymekaar gebring is deurdat die onderwerp "Rigting" uit die taakgebaseerde sillabus gekoppel is met die ruimtelike-aangrensingseffek van die kognitiewe multimedia-leerteorie.

\section{Slotopmerkings}

Uit die aanwending van twee navorsingsterreine kan gepoog word om verskillende take te ontwerp ten einde 'n rekenaarprogram vir nie-Afrikaanssprekende internasionale studente aan die US te ontwerp.

In die artikel is daar gepoog om 'n verbinding tussen die taakgebaseerde benadering tot leer en onderrig en rekenaargesteunde taalonderrig te maak met die doel om vernuwende elemente in Afrikaanse taalverwerwing op universiteitsvlak in te bring. Die doel van die artikel was om te toon hoe 'n taakgebaseerde rekenaarprogram ontwerp kan word aan die hand van Mayer (2001) se multimedia-instruksiebeginsels.

Die artikel bespreek in die eerste plek kortliks die taakgebaseerde benadering en fokus op die positiewe nut van die benadering ten opsigte van die verwerwing van tale, naamlik dat dit taalaanleerders kry om hulle huidige taalvaardighede te gebruik om sodoende taal te ontwikkel deur die gebruik daarvan. Voorts is Mayer se multimedia-leer teorie verduidelik met fokus op sy hipotese dat "humans engage in active learning by attending to relevant incoming information, organizing selected information into coherent mental representations, and integrating mental representations with previous knowledge” (Mayer 2001:40).

Die laaste gedeelte van die artikel poog om die inligting wat deur die vraelyste (as deel van die behoefte-analise) verkry is, prakties te gebruik. Een van die studente se onderwerpe is tesame met 'n multimedia-instruksiebeginsel gebruik sodat die navorsers kan aantoon hoe hulle hierdie inligting in 'n moontlike rekenaarprogam kan integreer. 
Die navorsers se deurlopende navorsing poog om die taakgebaseerde benadering en rekenaaronderrig vir die aanleer en verwerwing van Afrikaans by mekaar uit te bring. Empiriese data sal na die ontwerp van die rekenaarprogram verkry word en vorm nie deel van hierdie artikel se bevindings nie.

\section{Bronnelys}

Adendorff, E.M. 2012. Kompleksiteit in taakgebaseerde onderrig en leer van Afrikaans as tweede taal binne universiteitskonteks. Ongepubliseerde PhD. Universiteit Stellenbosch.

Berns, M. 1990. Functional approach to language and language teaching: another look. In S. Savinon en M. Berns (reds.). Communicative language teaching. Reading, Mass: AddisonWesley Publishing. pp. 3-21.

Brown, J.D. 2009. Foreign and second language needs analysis. In M.H. Long en C.J. Doughty (reds.). The handbook of language teaching. Chichester: Wiley-Blackwell. pp. 269-293.

Council for cultural co-operation education committee modern languages division, Strasbourg. 2001. Common European framework of reference for languages: Learning, teaching, assessment. Cambridge: Cambridge University Press.

Duran, G. en Ramaut, G. 2006. Tasks for absolute beginners and beyond: Developing and sequencing tasks at basic proficiency levels. In K. Van den Branden (red.) Task-based language education: From theory to practice. Cambridge: Cambridge University Press. pp. 47-75.

Ellis, R. 2003. Task-based language learning and teaching. Oxford: Oxford University Press.

González-Lloret, M. 2003. Designing task-based CALL to promote interaction: En Busca de Esmeraldas. Language Learning \& Technology 7(1): 86-104.

Klapper, J. 2003. Taking communication to task? A critical review of recent trends in language teaching. Language Learning Journal 27: 33-42.

Kruger, E. 2007. Die ontwikkeling van 'n rekenaarondersteunde taalonderrigprogram op grond van Afrikaanse Folklore. Per Linguam 23(1): 16-29.

Kruger, E. en Poser, M. 2007. Taakgerigte aktiwiteite om die kommunikasievaardighede van addisioneletaal-leerders in Afrikaans te ontwikkel. Tydskrif vir Taalonderrig 41(1): 1-13.

Larsen-Freeman, D. en Anderson, M. 2011. Techniques \& principles in language learning. Londen: Longman.

Mayer, R.E. 2001. Multimedia learning. New York: Cambridge University Press.

Mayer, R.E. 2009. Multimedia learning. New York: Cambridge University Press.

Mayer, R.E. 2010. Seeking a science of instruction. Instructional Science 38: 143-5. 
Mayer, R.E. 2011. Applying the science of learning. Boston: Pearson.

North, B. 2014. Putting the Common European Framework of Reference to good use. Language Teaching 47(2): 228-249.

Nunan, D. 2004. Task-based language teaching. Cambridge: Cambridge University Press.

Robinson, P. 2009. Syllabus design. In M.H. Long en C.J. Doughty (reds.). The handbook of language teaching. Chichester: Wiley-Blackwell. pp. 294-310.

Samuda, V. en Bygate, M. 2008. Tasks in second language learning. Basingstoke: Palgrave Macmillan.

Skehan, P. 1998. A cognitive approach to language learning. Oxford: Oxford University Press.

Sorden, S.D. 2005. A cognitive approach to instructional design for multimedia learning. Information Science Journal 8: 263-279.

Steenkamp, A. 2009. Focus on form in a framework for task-based isiXhosa in a specific purposes multimedia curriculum. Ongepubliseerde $\mathrm{PhD}$. Stellenbosch: Universiteit Stellenbosch.

Steenkamp, A. en Visser, M. 2011. Using cognitive complexity for the grading and sequencing of IsiXhosa tasks in the curriculum design of a communication course for education students. Per Linguam 27 (1): 11-27.

Sweller, J. 2005. Implications of cognitive load theory for multimedia learning. In R.E. Mayer (red.). The Cambridge handbook of multimedia learning. New York: Cambridge University Press. pp. 19-30.

Van Avermaet, P. en Gysen, S. 2006. From needs to tasks. Language learning needs in a taskbased approach. In K. Van den Branden (red.). Task-based language education: From theory to practice. Cambridge: Cambridge University Press. pp. 17-46.

Van den Branden, K. 2006. (red.). Task-based language education: From theory to practice. Cambridge: Cambridge University Press.

Van Merrienboer, J.J.G. 1997. Training complex cognitive skills. Engelwood Cliffs, NJ: Educational Technology Press. 